\title{
15. SULFUR IN PACIFIC DEEP-SEA SEDIMENTS (LEG 129) AND IMPLICATIONS FOR CYCLING OF SEDIMENT IN SUBDUCTION ZONES ${ }^{1}$
}

\author{
Jeffrey C. Alt ${ }^{2}$ and James W. Burdett ${ }^{2}$
}

\begin{abstract}
The mineralogy of S-bearing phases, S-contents, and S-isotopic compositions of sediments and interstitial waters were determined for three cores drilled during Leg 129 in the western Pacific. Pelagic clays, chalks, and radiolarites generally contain

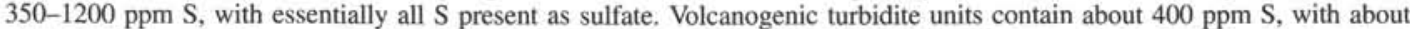
$10 \%-20 \%$ of total sulfur as pyrite-S and the remainder as sulfate. A single claystone from the base of Hole $802 \mathrm{~A}$ has high pyrite-S content $(1200 \mathrm{ppm})$ and contains a component of metalliferous sediment. The single analyzed chert has the highest sulfur content $(4020 \mathrm{ppm})$ with essentially all sulfur present as pyrite-S. Sulfate in pore waters ranges from seawater concentrations to nearly zero, and has $\delta^{34} \mathrm{~S}$ values ranging from seawater values $(+20 \%)$ to slightly enriched in ${ }^{34} \mathrm{~S}(+28 \%)$. Pyrite sulfur has ${ }^{34} \mathrm{~S}$ values of $-4.8 \%$ to $-37.1 \%$. These general trends are attributed to bacterial reduction of seawater sulfate, but the data do not fit simple models for downward diffusion of sulfate or closed-system reduction of buried sulfate. These complications are due to variations in the $\delta^{34} \mathrm{~S}$ of seawater sulfate in the past, uptake of sulfate by thaumasite $\left(\mathrm{Ca}_{3} \mathrm{Si}(\mathrm{OH})_{6} \mathrm{CO}_{3} \mathrm{SO}_{4}-12 \mathrm{H}_{2} \mathrm{O}\right)$ without isotopic fractionation in the Unit II tuff in Hole 802A, the presence of cherts that act as barriers to diffusion, and possible variations in the magnitude of isotopic fractionation during bacterial sulfate reduction.

The average sediment from Leg 129 contains around $850 \mathrm{ppm} \mathrm{S} \mathrm{(85 \%} \mathrm{as} \mathrm{sulfate,} 15 \%$ as sulfide), with a bulk $\delta^{34} \mathrm{~S}$ of $+12 \%$ a The bulk sulfur isotopic composition of deep-sea sediment is highly dependent on the proportion of pyrite-sulfur present, which varies depending on the sedimentary environment and history. The sedimentary sulfur component during subduction thus likely varies from near seawater values $(+20 \%)$ to possibly strongly negative values $(-20 \%)$.
\end{abstract}

\section{INTRODUCTION}

It has been suggested that the subduction of sediments and altered oceanic crust leads to the observed ${ }^{34} \mathrm{~S}$-enrichment of arc volcanics and to sulfur isotopic heterogeneities in the mantle (Rye et al., 1984; Ueda and Sakai, 1984; Chaussidon et al., 1987). Recent studies of altered oceanic crust, however, indicate that the $\delta^{34} \mathrm{~S}$ value of altered crust is changed only slightly relative to fresh mid-ocean ridge basalt (MORB) (about +1\%ovs. 0\%, respectively; Altetal., 1989; Alt and Anderson, 1991; Sakai et al., 1984), implying that the sediment component may contribute more to these effects during subduction than altered crust.

Because of their significance as reservoirs in the exogenic cycles of sulfur, carbon, and oxygen, a great deal of work has gone into documenting and understanding the geochemistry of sulfur in organic-rich shelf and marginal basin sediments (e.g., Kaplan et al., 1963; Goldhaber and Kaplan, 1974; Berner, 1964, 1982). In contrast, relatively little is known about sulfur in deep-sea sediments. Sulfate concentrations generally decrease with depth in interstitial waters from Deep Sea Drilling Project (DSDP) cores due to bacterial sulfate reduction (Gieskes and Lawrence, 1981), but little is known about the mineralogy of sulfur-bearing phases in the sediment or the sulfur isotopic composition of sediments and pore waters. Some data exist for surficial pelagic sediments (Volkov and Rozanov, 1983) and for selected pelagic carbonates and isolated black shale intervals in DSDP cores (Burdett et al., 1989; Bonnell and Anderson, 1987). Only averages or limited data are available for sulfur isotopes at depth in DSDP cores (Goldhaber and Kaplan, 1974; Krouse et al., 1977; Lew, 1981), however, so the sedimentary sulfur contribution to subduction remains poorly known.

This paper provides a preliminary study of the geochemistry of sulfur in three drill cores sampled by Ocean Drilling Program (ODP) Leg 129 in the western Pacific. The objectives of this study are to understand the

\footnotetext{
'Larson, R. L., Lancelot, Y., et al., 1992. Proc. ODP, Sci. Results, 129: College Station, TX (Ocean Drilling Program).

${ }^{2}$ The University of Michigan, Department of Geological Sciences, 1006 C.C. Little Building, Ann Arbor, MI 48109-1063, U.S.A.
}

geochemistry of sulfur through the documentation of concentrations, mineralogy, and isotopic compositions, and ultimately to use these results to constrain the sediment sulfur component during subduction. The Leg 129 sites were chosen because of their proximity to the well-documented Mariana Island Arc.

\section{LEG 129}

Three sites in the western Pacific were drilled during Leg 129 (Fig. 1). These are described in detail by Lancelot, Larson, et al. (1990) and are briefly summarized here. The lithostratigraphy of the cores is summarized in Table 1.

Hole 800A is located on Jurassic-age crust in the northern Pigafetta Basin (Fig. 1). In Hole $800 \mathrm{~A}$, we penetrated $498 \mathrm{~m}$ sediment and $46.4 \mathrm{~m}$ of dolerite sills (Fig. 2). Because the basement rocks occur on magnetic anomaly M33 (160 Ma) but are overlain by younger sediments (about $140 \mathrm{Ma}$ ) they are interpreted as intrusive sills rather than true basement.

Site 801 is located on Jurassic crust in the central Pigafetta Basin (Fig. 1). Three holes were drilled at this site: Hole $801 \mathrm{~A}$ penetrated $194 \mathrm{~m}$ of sediments; Hole $801 \mathrm{~B}$ penetrated $194 \mathrm{~m}$ to the base of the sediments at $461.6 \mathrm{~m}$ and $48.9 \mathrm{~m}$ into basement; and Hole $801 \mathrm{C}$ penetrated $100.6 \mathrm{~m}$ into Jurassic basement. The sediment lithostratigraphy for the site, shown in Figure 3, is generally similar to Hole 800A.

Hole $802 \mathrm{~A}$ is located on Jurassic-age crust in the Mariana Basin (Fig. 1), and penetrated $509 \mathrm{~m}$ sediments and $50.6 \mathrm{~m}$ into basalt (Fig. 4). The sediment section in this hole differs from the other sites in the presence of the Unit II tuff in Hole 802A (Fig. 4 and Table 1). Magnetic anomalies place the site on 165-Ma Jurassic crust, whereas the oldest sediments recovered are Aptian (about $115 \mathrm{Ma}$ ), suggesting that the basalts may not be true basement.

\section{METHODS}

The samples are of three types: interstitial water, sediment, and basalt. Subsamples of the interstitial water samples, which were squeezed from sediments and filtered aboard ship, were immediately 


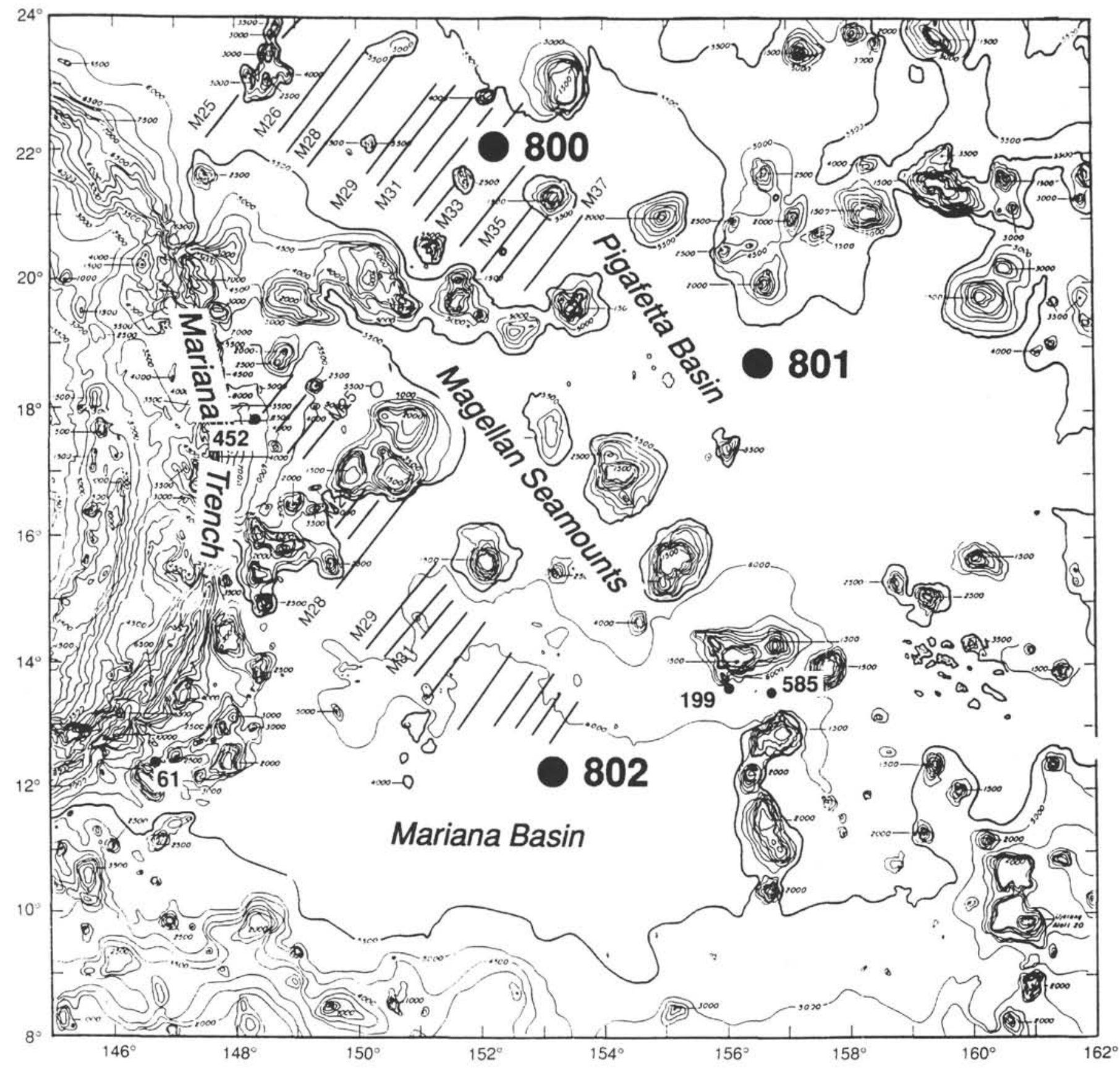

Figure 1. Location of Leg 129 drill sites. Bedrock isochrons determined from magnetic anomaly lineations (from Lancelot, Larson, et al., 1990). Bathymetry in meters.

sealed in serum bottles spiked with $\mathrm{CdCl}_{2}$ to precipitate any $\mathrm{H}_{2} \mathrm{~S}$ and kill bacteria. Sediment and basalt samples were selected to be representative of the recovered material, which is described in detail in Lancelot, Larson, et al. (1990). These samples were sealed in $\mathrm{N}_{2}$-filled plastic bags aboard ship and immediately frozen. The samples remained frozen until analysis, about 10 months later.

Several interstitial water samples contained a whitish precipitate, whereas other samples were clear. Those containing a precipitate were placed in sealed vessels through which nitrogen gas was flowed and were acidified to dissolve any $\mathrm{CdS}$ and drive off $\mathrm{H}_{2} \mathrm{~S}$. The gas was flowed through an $\mathrm{AgNO}_{3}$ solution to trap sulfide as $\mathrm{H}_{2} \mathrm{~S}$. No sulfide was detected in any of these samples. All interstitial water samples were acidified and heated to near boiling, and $\mathrm{BaCl}_{2}$ solution was added to precipitate $\mathrm{SO}_{4}$ as $\mathrm{BaSO}_{4}$ for isotopic analysis.
Sulfur was extracted from sediments using a stepwise technique to separate various forms of sulfur. Sediments were dried at $40^{\circ} \mathrm{C}$, and 10 - to 20 -g samples were ground to powder and dried at $80^{\circ} \mathrm{C}$. In the first step, sediments were ultrasonically washed in $150 \mathrm{~mL}$ of distilled water for $5 \mathrm{~min}$, and were centrifuged, filtered, and then dried at $80^{\circ} \mathrm{C}$. Sulfate in the wash was precipitated as $\mathrm{BaSO}_{4}$, and is referred to as water-soluble sulfate. In the second step, the sediment residues from the first extraction were reacted with $6 \mathrm{~N} \mathrm{HCl}$ at $80^{\circ} \mathrm{C}$ for $1 \mathrm{hr}$ in sealed vessels through which nitrogen gas was flowed, in order to extract monosulfide sulfur and acid-soluble sulfate. The nitrogen carrier gas and any $\mathrm{H}_{2} \mathrm{~S}$ evolved was flowed through $\mathrm{AgNO}_{3}$ solution to trap sulfide as $\mathrm{Ag}_{2} \mathrm{~S}$. In the third step, the residues were reacted with $\mathrm{CrCl}_{2}-\mathrm{HCl}$ solution under nitrogen for at least $2 \mathrm{hr}$ to extract pyrite sulfur (Canfield et al., 1986), which was precipitated as $\mathrm{Ag}_{2} \mathrm{~S}$. Soluble 
Hole 800A lithology

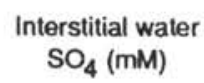

Interstitial water

$\mathrm{SO}_{4}(\mathrm{mM})$

Sediment sulfur content (ppm)

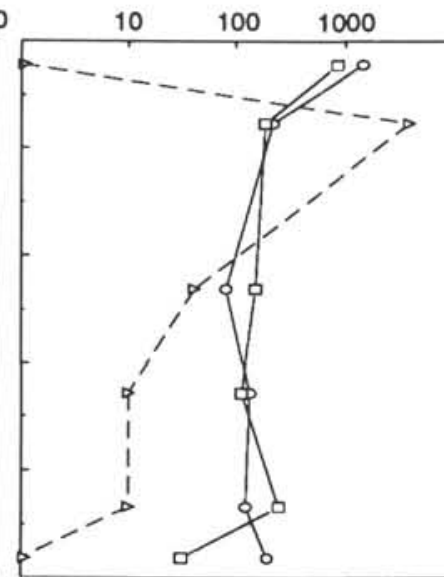

$\delta^{34} S$ Sediment

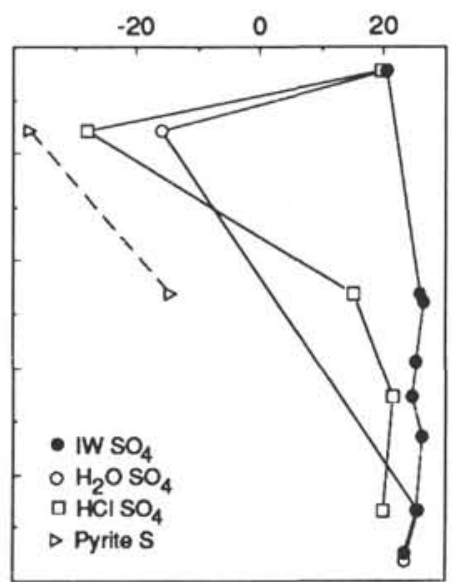

$\delta^{34} \mathrm{~S}$ coeval

seawater $\mathrm{SO}_{4}$

$\begin{array}{llll}16 & 18 & 20 & 22\end{array}$

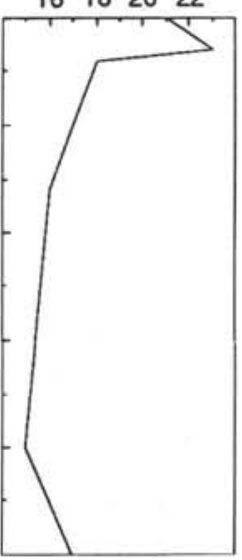

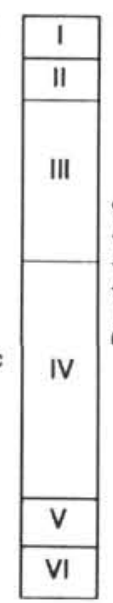

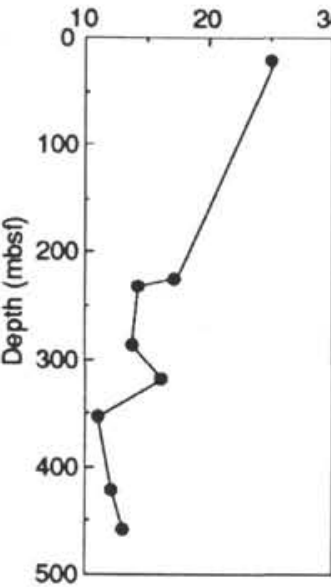

(2)

Figure 2. Lithostratigraphy and sulfur data for Hole $800 \mathrm{~A}$. IW = interstitial water; $\mathrm{H}_{2} \mathrm{O} \mathrm{SO}_{4}=$ water-soluble sulfate; $\mathrm{HCl} \mathrm{SO} \mathrm{S}_{4}=$ acid-soluble sulfate; pyrite- $\mathrm{S}=$ pyrite sulfide. Lithostratigraphy from Lancelot, Larson, et al. (1990).

Hole 801A, B lithology

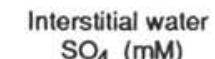

$\mathrm{SO}_{4}(\mathrm{mM})$

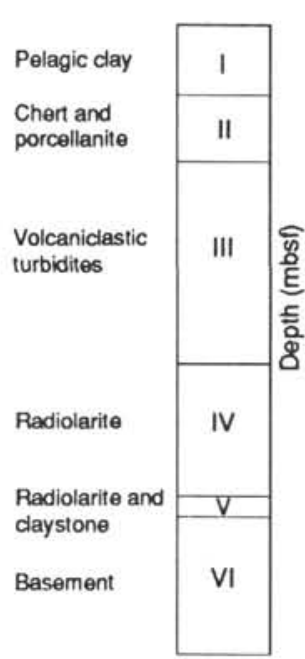

Sediment sulfur content (ppm)

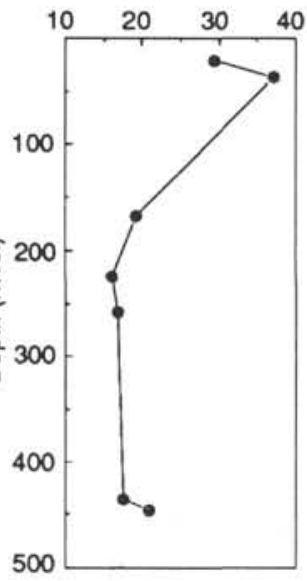

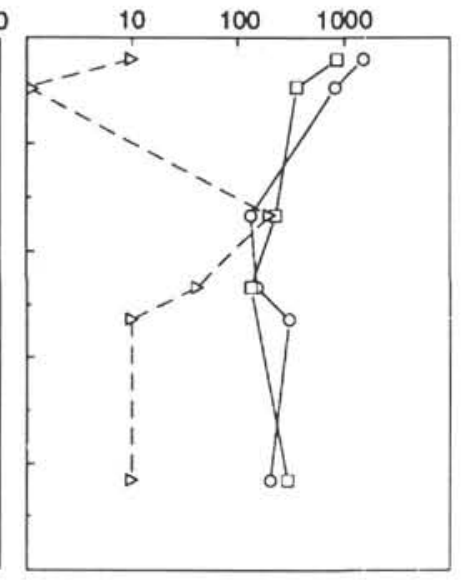

$\delta^{34} \mathrm{~S}$ Sediment

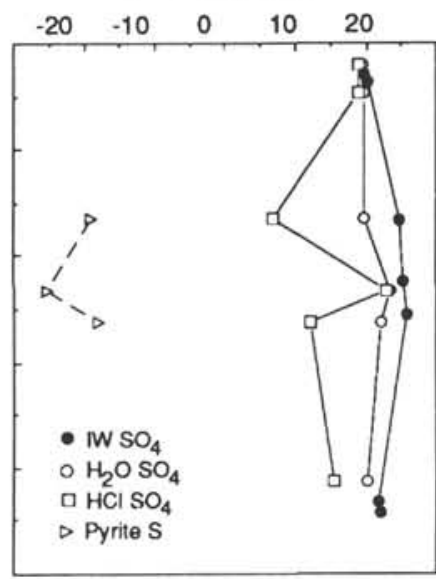

$\delta^{34} \mathrm{~S}$ coeval seawater $\mathrm{SO}_{4}$

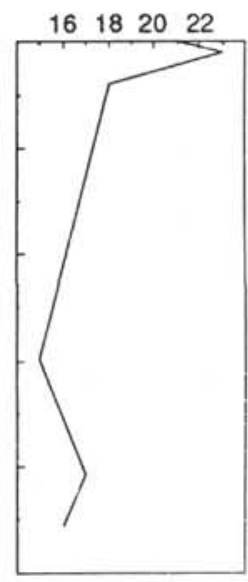

Figure 3. Lithostratigraphy and sulfur data for Site 801. Symbols as in Figure 2.

sulfate from the acid extractions was precipitated as $\mathrm{BaSO}_{4}$, and is referred to as acid-soluble sulfate.

Pyrite for S-isotopic analysis was hand-picked from veins in several basalt samples. Sulfate was extracted from two samples of thaumasite $\left(\mathrm{Ca}_{3} \mathrm{Si}(\mathrm{OH})_{6} \mathrm{CO}_{3} \mathrm{SO}_{4}-12 \mathrm{H}_{2} \mathrm{O}\right)$, which was physically separated from veins in sediment by warming $0.1 \mathrm{~g}$ of the powdered mineral in $100 \mathrm{~mL}$ of $3 \mathrm{~N} \mathrm{HCl}$ solution and, following the addition of saturated $\mathrm{BaCl}_{2}$ solution, precipitated as $\mathrm{BaSO}_{4}$.

Sulfur concentrations were gravimetrically determined for the different extractions. $\mathrm{SO}_{2}$ gas for isotopic analysis was prepared by combusting sulfide with $\mathrm{Cu}_{2} \mathrm{O}$ under vacuum at $1000^{\circ} \mathrm{C}$, and $\mathrm{BaSO}_{4}$ was combusted under vacuum with $\mathrm{Na}$-metaphosphate at $1000^{\circ} \mathrm{C}$ (Halas et al., 1982). Sulfur isotope ratio analyses were performed on a VG 602 E mass spectrometer at the University of Michigan Stable Isotope Laboratory and are reported as standard delta $(\delta)$ notation relative to Cañon Diablo Troilite (CDT). Standardization is based on $\delta^{34} S$ values of $+17.09 \%$ for NBS 123 sphalerite, and $+20.32 \%$ for NBS $127 \mathrm{BaSO}_{4}$ (Hut, 1987). Analytical error based on multiple analyses of standards is $\pm 0.2 \%$ for sulfides and $\pm 0.4 \%$ ofor sulfates.

The mineralogy of sulfides and sulfates was determined by optical examination of polished thin sections, plus scanning electron microscopy (SEM) of thin sections and rock chips. Back-scattered electron imaging (BSE) and energy dispersive X-ray analyses (EDS) were employed in SEM analyses.

\section{RESULTS}

Results of sulfur extractions and isotopic analyses are given in Table 2 and shown in Figures 2-4. The sulfate concentrations in IW (interstitial water) samples generally decrease with depth and then 
Table 1. Lithostratigraphy of the Leg 129.

\begin{tabular}{|c|c|c|c|c|c|}
\hline Hole & Unit & $\begin{array}{l}\text { Depth } \\
\text { (mbsf) }\end{array}$ & $\begin{array}{l}\text { Sedimentation rate } \\
\qquad(\mathrm{m} / \mathrm{m} . \mathrm{y} .)\end{array}$ & Age & Description \\
\hline \multirow[t]{5}{*}{$800 \mathrm{~A}$} & 1 & $0-38$ & $<0.5$ & $\begin{array}{c}\text { Cenozoic to Late } \\
\text { Cretaceous }\end{array}$ & $\begin{array}{l}\text { Brown pelagic clay, unlithified, highly } \\
\text { disturbed by drrilling. Clay aggregates, } \\
\text { RSOs, phillipsite, barite, quartz, feldspar. }\end{array}$ \\
\hline & II & $38-78.2$ & $<2$ & Late Cretaceous & Brown chert and porcellanite. Low recovery. \\
\hline & III & $78.2-228.6$ & 6 & Albian to Cenomanian & $\begin{array}{l}\text { Gray cherts and siliceous limestone turbidites. } \\
\text { Increasing silicified limestone content } \\
\text { downward, increased clay at base. } \\
\text { Transitional to Unit IV. Pyrite locally } \\
\text { replaces radiolarians. Deposited beneath } \\
\text { subequatorial high-productivity zone. }\end{array}$ \\
\hline & IV & $228.6-449.6$ & 20 & Aptian & $\begin{array}{l}\text { Volcanogenic turbidites, clays to sandstones. } \\
\text { Volcanic glass, igneous rock fragments, } \\
\text { feldspars, zeolites, calcite, opal, } \\
\text { groundmass green clays. Related to } \\
\text { widespread Cretaceous Pacific volcanism. } \\
\text { Mainly dark green with interbedded red } \\
\text { claystones. }\end{array}$ \\
\hline & VI & $\begin{array}{l}449.6-498.1 \\
498.1-544.5\end{array}$ & $0.2-1$ & $\begin{array}{r}\text { Valanginian to } \\
\text { Barremian }\end{array}$ & $\begin{array}{l}\text { Microlaminated clayey radiolarites and } \\
\text { siliceous claystones. Variations in silica } \\
\text { and clay contents. Thin Mn-oxide veins. } \\
\text { Dolerite sills with chert interlayers. }\end{array}$ \\
\hline \multirow[t]{2}{*}{$801 \mathrm{~A}$} & I & $0-63.8$ & $<1$ & $\begin{array}{l}\text { Cenozoic to } \\
\text { Maestrichtian- } \\
\text { Campanian }\end{array}$ & $\begin{array}{l}\text { Brown pelagic clay. Soft, highly disturbed by } \\
\text { drilling. Upper half enriched in RSOs and } \\
\text { zeolites. }\end{array}$ \\
\hline & II & $63.8-126.5$ & 3 & $\begin{array}{l}\text { Campanian to } \\
\text { Cenomanian }\end{array}$ & $\begin{array}{l}\text { Brown chert and porcellanite. Low recovery. } \\
\text { Equatorial high-productivity zone, but } \\
\text { Mn-oxide veins present. Transitional to } \\
\text { Unit III. }\end{array}$ \\
\hline \multirow[t]{3}{*}{$801 \mathrm{~B}$} & III & $126.5-318.3$ & $0.5-12$ & Cenomanian to Albian & $\begin{array}{l}\text { Volcaniclastic turbidites with minor pelagic } \\
\text { intervals. Claystone to sandstone. Glass, } \\
\text { rock fragments, feldspars, pyroxenes, clays, } \\
\text { Fe-oxides, zeolites, quartz, accessory } \\
\text { minerals. Related to Pacific Cretaceous } \\
\text { volcanism. }\end{array}$ \\
\hline & IV & $318.3-443.3$ & $0.5-10$ & $\begin{array}{r}\text { Valanginian to } \\
\text { Oxfordian }\end{array}$ & $\begin{array}{l}\text { Brown radiolarite. Upper } 81 \mathrm{~m} \text { is clay poor with } \\
\text { abundant chert, related to equatorial } \\
\text { high-productivity zone. Lower } 44 \mathrm{~m} \text { is clay } \\
\text { rich with less chert. Common Fe-Mn oxides. }\end{array}$ \\
\hline & $\mathrm{V}$ & $443.3-462.0$ & 1.3 & & $\begin{array}{l}\text { Alternating red radiolarite and claystone. Basal } \\
\text { metalliferous sediments and pelagic } \\
\text { sediment. }\end{array}$ \\
\hline
\end{tabular}

increase slightly in the lowermost $100 \mathrm{~m}$ in all three holes. Increases in sulfate concentrations occur at about 40 mbsf (meters below seafloor) in Holes $801 \mathrm{~A}$ and $802 \mathrm{~A}$, and there is a minimum in sulfate at about $100 \mathrm{mbsf}$ in Hole $802 \mathrm{~A}$ (Figs. 3 and 4). The $\delta^{34} \mathrm{~S}$ values of IW sulfate generally increase with depth in all holes, from seawater values $(+20.5 \%)$ in the uppermost samples to values of $+26 \%$ to $+28 \%$ Holes $800 \mathrm{~A}$ and 801 exhibit maxima in $\delta^{34} \mathrm{~S}$ of IW sulfate about halfway down the section, then $\delta^{34} \mathrm{~S}$ decreases slightly by $3 \%-4 \%$ to the base of the sediments (Figs. 2 and 3 ).

Water-soluble sulfate contents of the sediments generally follow IW sulfate concentrations: water-soluble sulfate exhibits an overall decrease with depth in Hole 801 (Fig. 3), and in Hole 802A watersoluble sulfate decreases to a minimum at about $100 \mathrm{mbsf}$, then increases slightly and remains more or less constant with depth (Fig. 4). The $\delta{ }^{34} \mathrm{~S}$ values of water-soluble sulfate in the sediments (mostly $+20.3 \%$ to $+27.6 \%$ ) are similar to those for IW samples, and the trends with depth for the two are also comparable (Figs. 2-4). These features are consistent with water-soluble sulfate representing interstitial pore waters in the sediments.

The contents and trends with depth of acid-soluble sulfate in the sediments are generally similar to those of water-soluble sulfate (Figs. $2-4)$. The $\delta^{34} S$ values of acid-soluble sulfate are also generally comparable to the values for water-soluble sulfate in the same samples and exhibit overall similar trends with depth (Figs. 2-4). Because the sediment from the first extraction step was centrifuged and dried, acid-soluble sulfate from step 2 probably contains a component of residual pore-water sulfate left from the water extraction. Water-torock ratios for the water extraction were about 10:1. Assuming that the amount of water in the wet rock-powder cake remaining in the centrifuge tube following decantation of the water wash is similar to that originally present in the wet sediment, the IW sulfate remaining in the rock powder cake would be diluted tenfold. This residual sulfate, which was dried and ultimately incorporated into the acidsoluble sulfate extraction, should thus be about $10 \%$ of the water-soluble sulfate content. Sulfate-bearing phases identified in the cores include celestite and thaumasite $\left(\mathrm{Ca}_{3} \mathrm{Si}(\mathrm{OH})_{6} \mathrm{CO}_{3} \mathrm{SO}_{4}-12 \mathrm{H}_{2} \mathrm{O}\right.$; Karpoff et al., this volume) and these contribute to the acid-soluble sulfate fraction. Sulfate extracted from thaumasite separated from veins in two samples has $\delta^{34} \mathrm{~S}$ values of $+19.5 \%$ to $+20.4 \%$ a similar to IW from surrounding cores $(+20.5 \%$ to $+21.4 \%)$. Acid-soluble sulfate is also derived from sulfate in carbonate, and possibly from sulfate incorporated into the clay fraction as aluminosulfates (Volkov and Rozanov, 1983).

Acid-soluble sulfate in several samples has lower $\delta^{34} \mathrm{~S}$ values than coexisting water-soluble sulfate (Figs. $2-4$ ). Pyrite-sulfur has low $\delta^{34} \mathrm{~S}$ values $(-4.8 \%$ to $-37.1 \%$, Table 2$)$, and the $\delta^{34} \mathrm{~S}$ of acid-soluble sulfate generally decreases with increasing pyrite-sulfur contents (Fig. 5). The 
Table 1 (continued).

\begin{tabular}{|c|c|c|c|c|c|}
\hline Hole & Unit & $\begin{array}{l}\text { Depth } \\
\text { (mbsf) }\end{array}$ & $\begin{array}{l}\text { Sedimentation rate } \\
\qquad(\mathrm{m} / \mathrm{m} . \mathrm{y} .)\end{array}$ & Age & Description \\
\hline \multirow[t]{10}{*}{$802 \mathrm{~A}$} & I & $0-14.6$ & $<1$ & $\begin{array}{l}\text { Late Pliocene to late } \\
\text { Quaternary }\end{array}$ & $\begin{array}{l}\text { Brown pelagic clay. Clays, RSOs, zeolites, } \\
\text { micronodules, quartz, radiolarian spicules. }\end{array}$ \\
\hline & II & $14.6-237.4$ & $0.11-15$ & $\begin{array}{l}\text { middle Pliocene to } \\
\text { early Miocene }\end{array}$ & $\begin{array}{l}\text { Tuff (volcaniclastic turbidites). Volcanic ash, } \\
\text { lapilli, volcanic glass, palagonite, feldspar, } \\
\text { clinopyroxene, olivine, igneous rock } \\
\text { fragments, Fe-oxides, opaque minerals, } \\
\text { smectite, zeolite, calcite. Upper } 146 \mathrm{~m} \\
\text { interbedded with pelagic claystone; lower } \\
76.8 \mathrm{~m} \text { interbedded with chalk, transitional } \\
\text { to Unit III. Equatorial high-productivity } \\
\text { zone. Zeolites and thaumasite in veins and } \\
\text { vugs } 83-162 \text { mbsf. }\end{array}$ \\
\hline & III & $237.4-329.9$ & $0.7-12$ & $\begin{array}{l}\text { Early Miocene to } \\
\text { upper Paleocene }\end{array}$ & $\begin{array}{l}\text { Nannofossil chalk turbidites. } 20 \text { m.y. hiatus } \\
\text { divides upper clay-poor sediment from } \\
\text { lower clay-rich half. Lower half affected by } \\
\text { silica diagenesis. }\end{array}$ \\
\hline & IV & $329.9-349.2$ & $0.2-4$ & $\begin{array}{c}\text { Paleocene to late } \\
\text { Campanian }\end{array}$ & Pelagic clay, similar to Unit I. Hiatus present? \\
\hline & V & $349.2-460.0$ & & $\begin{array}{l}\text { Late Campanian to } \\
\text { Coniacian- } \\
\text { Cenomanian }\end{array}$ & $\begin{array}{l}\text { Volcaniclastic turbidites, debris flows to } \\
\text { claystones. Similar to such units in the } \\
\text { other holes. Secondary zeolites, glauconite, } \\
\text { celestite. Formed beneath equatorial } \\
\text { high-productivity zone. }\end{array}$ \\
\hline & VI & $460.0-469.9$ & 2 & $\begin{array}{c}\text { Cenomanian to } \\
\text { Coniacian }\end{array}$ & $\begin{array}{l}\text { Interbedded brown pelagic claystone and } \\
\text { reworked radiolarite. Fe-Mn oxide } \\
\text { laminations, local pyrite. }\end{array}$ \\
\hline & VII & $469.9-497.1$ & 1.5 & $\begin{array}{l}\text { Late Aptian? to late } \\
\text { Coniacian }\end{array}$ & $\begin{array}{l}\text { Turbiditic calcareous claystone and pelagic } \\
\text { radiolarite. }\end{array}$ \\
\hline & VIII & $497.1-499.5$ & 1.5 & $\begin{array}{l}\text { Late Aptian? to } \\
\text { Cenomanian }\end{array}$ & $\begin{array}{l}\text { Brown pelagic claystone with thin interbeds of } \\
\text { redeposited red radiolarite. }\end{array}$ \\
\hline & IX & $499.5-509.1$ & 1.5 & & $\begin{array}{l}\text { Volcaniclastic turbidites and tuffaceous } \\
\text { claystone. Abundant secondary clay } \\
\text { minerals, silica, and calcite. Seamount } \\
\text { source, low-productivity zone. }\end{array}$ \\
\hline & $\mathrm{X}$ & $509.1-559.7$ & & Aptian & Basalt pillow lavas and one flow. \\
\hline
\end{tabular}

Note: After Lancelot, Larson, et al., 1990.

$\delta^{34} \mathrm{~S}$ of acid-soluble sulfate also decreases with decreasing $\delta^{34} \mathrm{~S}_{\text {(acid- }}$ soluble sulfate) ${ }^{-} \delta^{34} S_{\text {(pyrite-sulfur). }}$. These observations suggest that the low $\delta^{34} \mathrm{~S}$ values of acid-soluble sulfate in some samples are caused by oxidation of low $-\delta^{34} \mathrm{~S}$ sulfide, probably during drying of the sample after extraction of water-soluble sulfate. The oxidized sulfide could be derived from pyrite in the sediment or possibly from sulfide in solution. Similar trends of decreasing $\delta^{34} \mathrm{~S}$ of sulfate with increasing proportion of sulfide in both deep-sea and marginal basin cores have also been attributed to oxidation of sulfide (Kaplan et al., 1963; Krouse et al., 1977; Lew, 1981). Acid-soluble sulfate thus represents sulfur from various sites in the sediments: sulfate-bearing phases (celestite, thaumasite), carbonate, residual interstitial water sulfate left from the water extraction, small amounts of oxidized sulfide, and perhaps sulfate in the clay phase.

Little or no acid-soluble sulfide was detected from step 2 of the extractions. At the maximum, only traces were indicated by the presence of a dark brown to black ring of $\mathrm{Ag}_{2} \mathrm{~S}$ on the tip of the glass tube carrying gases into the $\mathrm{Ag}_{2} \mathrm{NO}_{3}$ trap (listed as "trace" in Table 2). Additional sulfur may be present as sulfate in barite in the Leg 129 sediments, but extractions of barite sulfur have not yet been performed because of time limits on submission of this manuscript. These extractions and isotopic analyses are being undertaken in order to complete the analysis of sulfur in these sediments.
Pyrite-sulfur contents are highly variable in the Leg 129 sediments, from below detection to $4020 \mathrm{ppm}$ (Table 2). Pyrite-sulfur contents were too low to obtain enough sulfur for isotopic analysis in many samples, but measured $\delta^{34} \mathrm{~S}$ values of pyrite-sulfur are low, ranging from $-4.8 \%$ to $-37.1 \%$ (Table 2 ). Secondary pyrite separated from veins in basalts has low $\delta^{34} \mathrm{~S}$ values of $-18.1 \%$ to $-41.7 \%$ (Table 2).

\section{Pelagic Clays}

The pelagic clays at the tops of Holes $800 \mathrm{~A}$ and $801 \mathrm{~A}$ have relatively high total sulfur contents (1160-2440 ppm, Table 2). These sediments are unlithified, with very high porosity and water contents (around $80 \%$ and $60 \%$, respectively, Lancelot, Larson, et al., 1990). Little or no pyrite-sulfur is present in these samples and essentially all sulfur is present as sulfate, with $60 \%-70 \%$ as water-soluble sulfate in pore fluids. This sulfur distribution is consistent with the oxidized, brown color of the sediments and the absence of visible sulfide in thin-section and SEM observations. Barite has been identified by SEM-EDS, but barite sulfur extractions have not yet been performed. Water-soluble sulfate in the pelagic clays has $\delta^{34} \mathrm{~S}$ values of $+20.4 \%$ to $+20.6 \%$, essentially identical to seawater $(+20.9 \%$, Rees et al., 1978). The slightly lower values of acid-soluble sulfate in these samples 


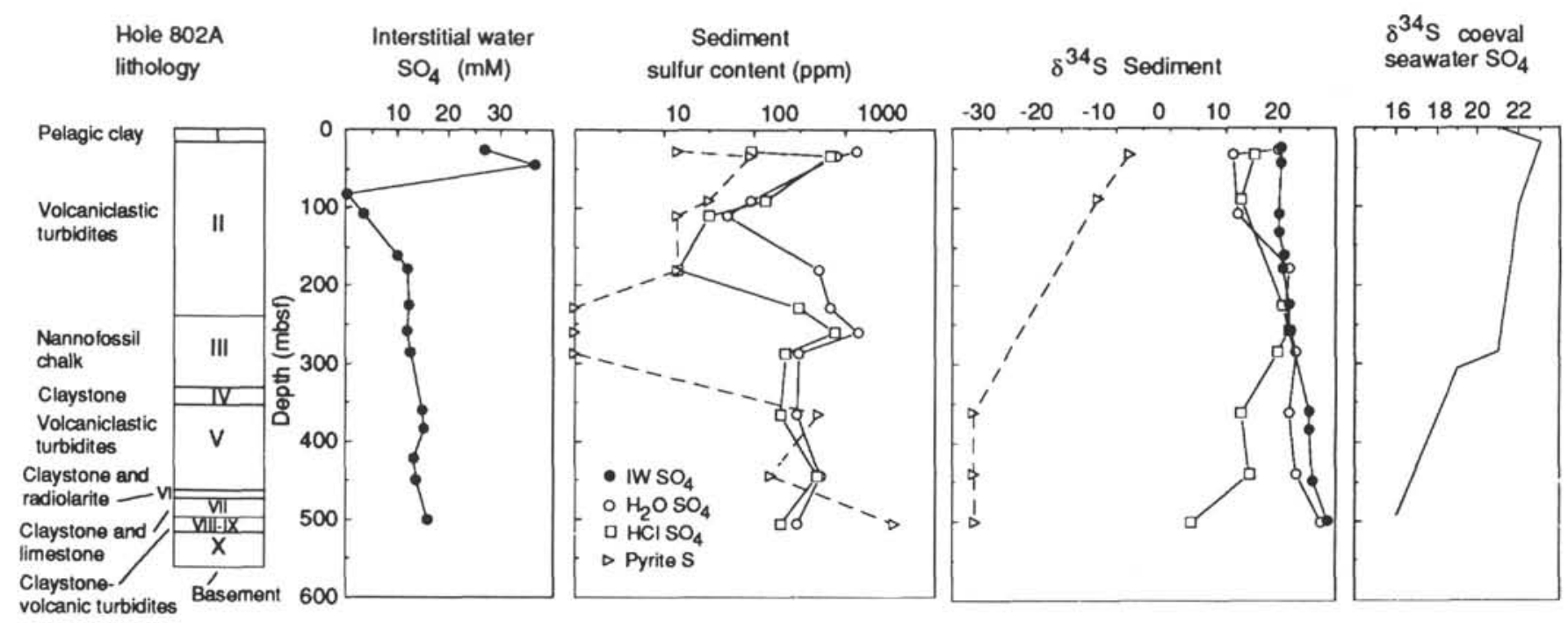

Figure 4. Composite lithostratigraphy and sulfur data for Hole 802A. Symbols as in Figure 2.

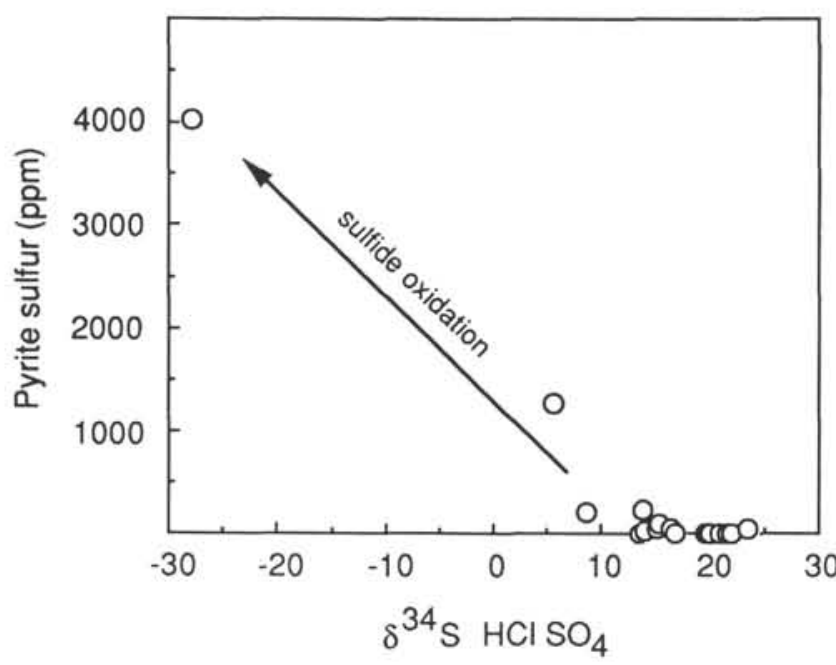

Figure 5. Pyrite-sulfur contents of sediment vs. $\delta^{34} \mathrm{~S}$ of acid-soluble sulfate. Arrow indicates trend of decrease in $\delta^{34} \mathrm{~S}$ of acid-soluble sulfate at increasing pyrite contents.

$(+19.7 \%$ to $+19.9 \%)$ are probably due to incorporation of small amounts of oxidized sulfide. The concentrations and isotopic compositions of IW sulfate from the pelagic clay units at the tops of Holes 800A and 801A are also close to seawater values (Table 2). These pelagic clays are open to diffusion of seawater, and essentially all the sulfur in the sediments is seawater sulfate.

A pelagic clay interval within the volcanic tuff of Hole 802A (Unit II, Sample 129-802A-13R-2, 71-73 cm, 109 mbsf) has a much lower total sulfur content $(60 \mathrm{ppm})$ than the clays at the tops of the cores (Table 2). The porosity and water content of this sample are identical to those at the tops of the cores (Lancelot, Larson, et al., 1990), but the sulfate content of the pore fluids is low at this depth in Unit II (about $4 \mathrm{mM}$, Table 2). Thus, as in the uppermost clays, sulfur is present dominantly as oxidized sulfur in the pore fluids of Sample $129-802 \mathrm{~A}-13 \mathrm{R}-2,71-73 \mathrm{~cm}$, but the low sulfate concentration in the pore fluids causes a concomitant low total sulfur content of the bulk sediment. Sulfate in this sample has a $\delta^{34} \mathrm{~S}$ value of $+13.3 \%$ a This value is relatively low for sulfates, which are generally closer to seawater values (about $+21 \%$, Table 2 ), but is similar to water- and acid-soluble sulfates from nearby Cores 129-800A-5R through 129-800A-11R in the tuff $\left(\delta^{34} \mathrm{~S}=+12.7 \%\right.$ o to $+16.3 \%$, Table 2$)$. These relatively low sulfate $\delta^{34} \mathrm{~S}$ values are attributed to incorporation of some oxidized sulfide during sample preparation. Traces of pyrite were observed in the thin section of Sample 129-802A-13R-2, 71-73 cm.

\section{Volcanogenic Turbidites}

Total sulfur contents of the volcanogenic turbidites and tuff units in the Leg 129 cores range from 140 to $690 \mathrm{ppm}$, averaging about 400 ppm (Table 2). Contents of water- and acid-soluble sulfate are roughly subequal, with lesser amounts of pyrite-sulfur present. Small amounts of pyrite and chalcopyrite occur as 1 - to $25-\mu \mathrm{m}$ irregular to round grains in altered glass and interstitial areas.

Sulfur in the shallowest sample in the Unit II tuff in Hole 802A (Sample 129-802A-4R-2, 98-101 cm) is dominated by seawater sulfate in pore fluids (water-soluble sulfate, Table 2). This sample is from $26.78 \mathrm{mbsf}$, immediately below the unconsolidated pelagic clay of Unit I, and has a high porosity and water content (Lancelot, Larson, et al., 1990), and IW in nearby cores has seawater sulfate concentrations and isotopic compositions (Section 129-802A-4R-1, 140-150 $\mathrm{cm}$, Table 2). Pore fluids are thus likely in communication with seawater as in the overlying pelagic clay, the sediment is oxidized, and sulfur is dominated by seawater sulfate.

Beneath this sample, pyrite-sulfur contents increase and then decrease steadily with depth (Fig. 4). The decrease in pyrite-sulfur contents correlates with the increasing proportion of chalk and increasing $\mathrm{CO}_{2}$ contents with depth (Lancelot, Larson, et al., 1990), transitional to the chalks of Unit III, which contain no detectable pyrite-sulfur (Fig. 4). Water- and acid-soluble sulfate in the volcanogenic units have $\delta^{34} S$ values ranging from $+8.7 \%$ to $+27.6 \%$ (Table 2 ), both greater and less than present-day seawater. As previously discussed, the low values for acidsoluble sulfate are attributed to oxidation of sulfide during prior water extractions. A similar explanation can account for several low $\delta^{34} S$ values of water-soluble sulfate (Table 2). Such low $\delta^{34} S$ values do not occur in IW sulfate samples squeezed aboard ship (Table 2), suggesting that the oxidation of sulfide detected in water-soluble sulfate occurred during storage or extraction. 
Table 2. Sulfur data for Leg 129 cores.

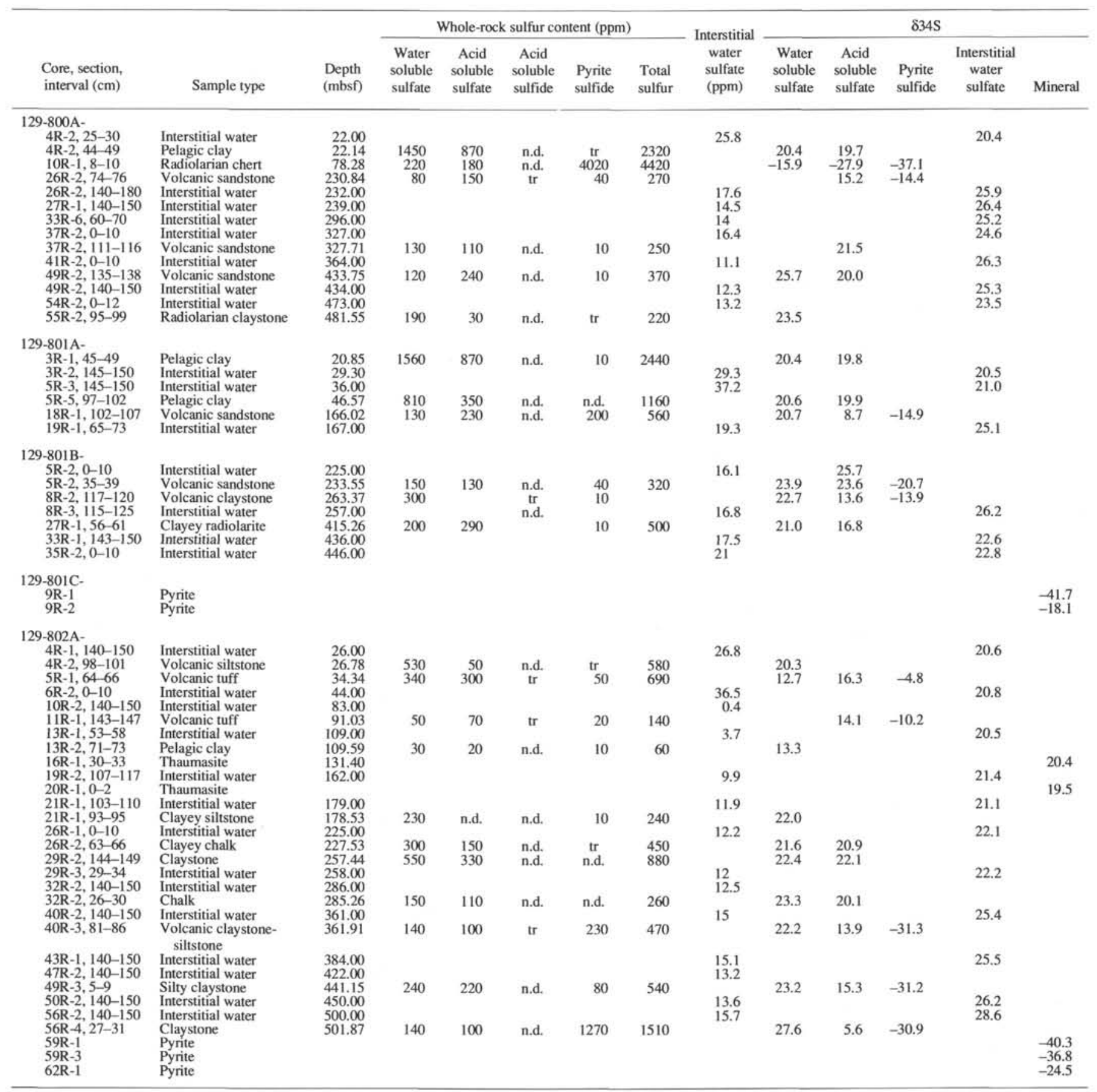

Note: $\mathrm{tr}=$ trace; $\mathrm{n} . \mathrm{d} .=$ not detected; $\delta 34 \mathrm{~S}$ in parts per million $(\%)$ CDT; interstitial water sulfate concentrations from Lancelot, Larson, et al. (1990).

\section{Chalk}

Sulfur in the chalk from Hole $802 \mathrm{~A}$ (Samples 129-802A-32R-2, $26-30 \mathrm{~cm}$, and $129-802 \mathrm{~A}-26 \mathrm{R}-2,63-66 \mathrm{~cm}$ ) is dominated by sulfate, and sulfate $\delta^{34} \mathrm{~S}$ values of $+20.1 \%$ oto $+23.3 \%$ are elevated somewhat relative to present-day seawater (Table 2). No sulfide was detected in the acid extractions or in optical examination of thin sections.

\section{Claystone}

The basal claystone in Unit VIII at the bottom of Hole 802A is dominated by pyrite-sulfur, with lesser amounts of sulfate. Water-soluble sulfate is enriched in ${ }^{34} \mathrm{~S}$ compared to seawater (Table 2), whereas the acid-soluble sulfate has a relatively low $\delta^{34} \mathrm{~S}$ value $(+5.6 \%)$ consistent with the presence of some oxidized sulfide. Pyrite sulfur in this sample 


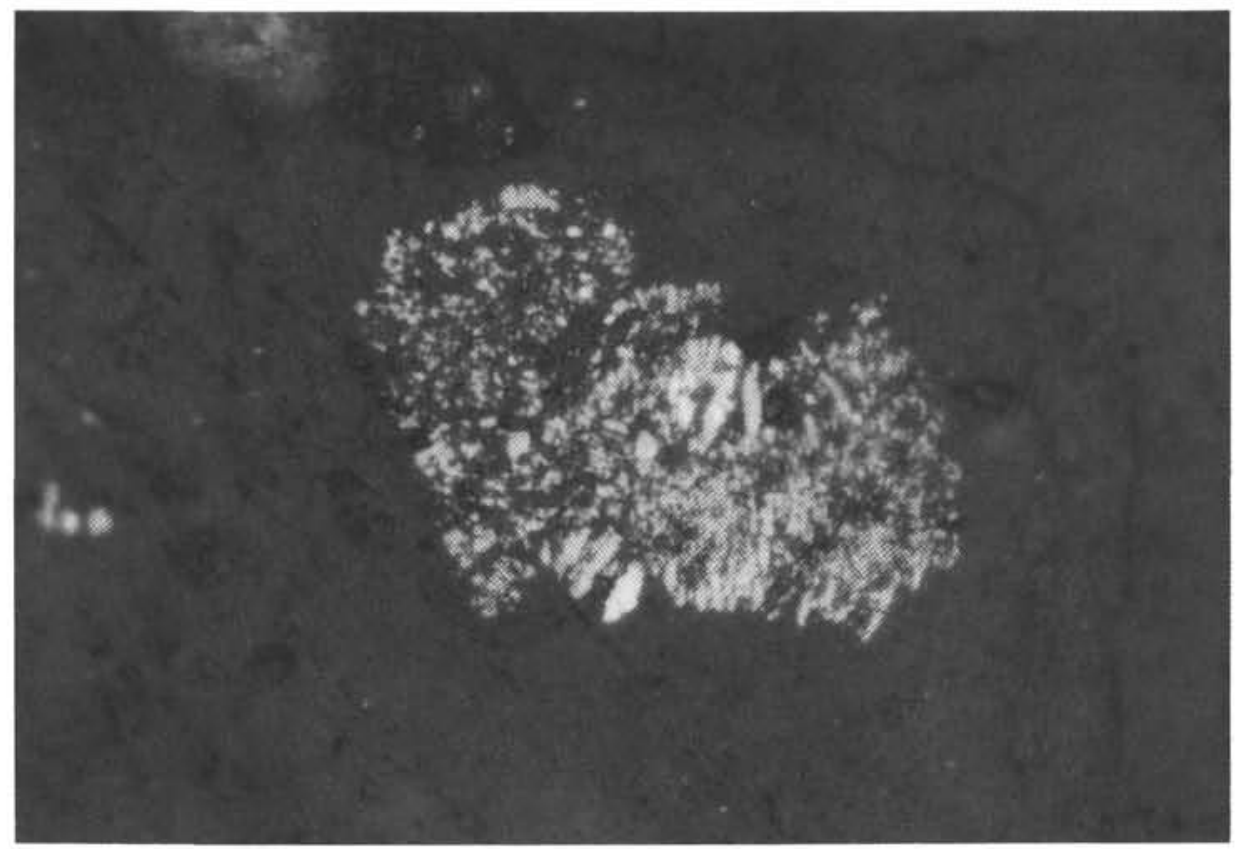

A

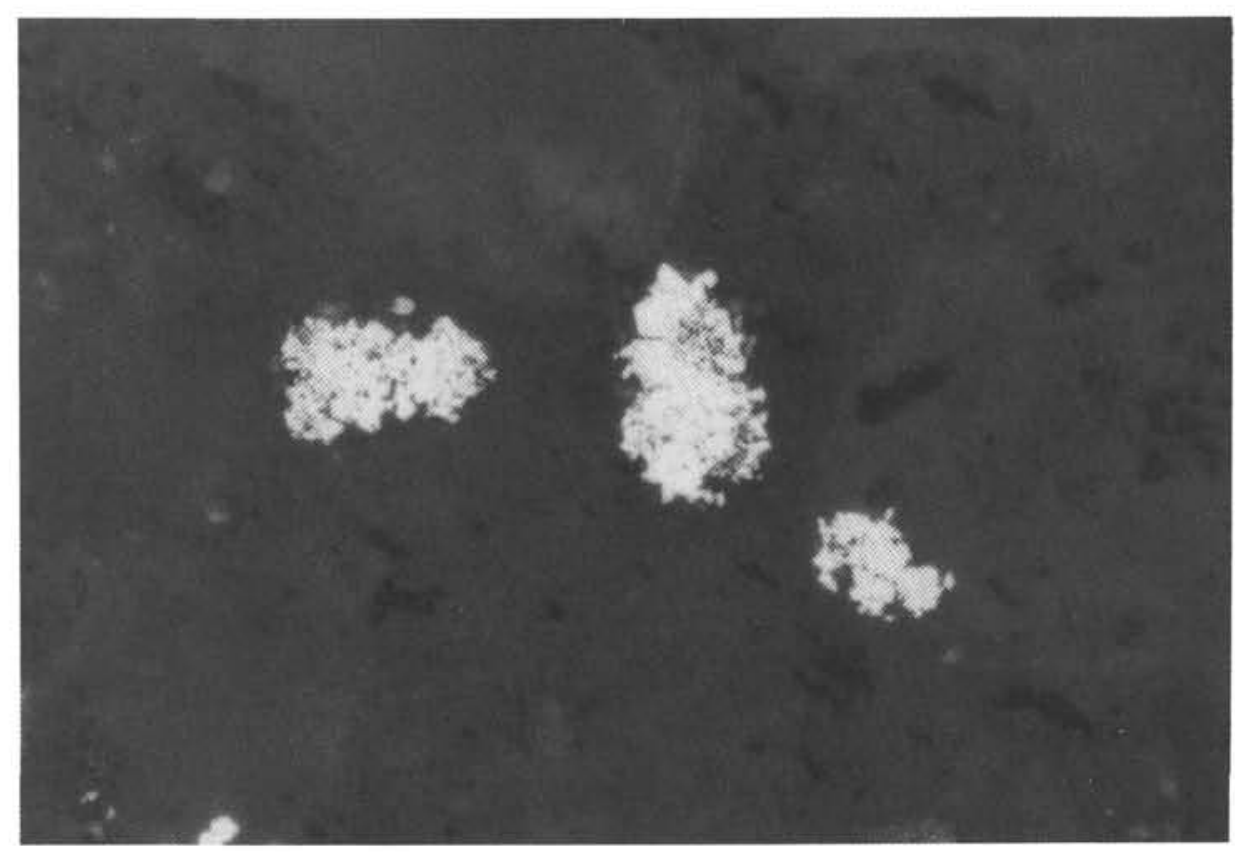

B

Figure 6. Photomicrographs of sulfide phases in Leg 129 sediments. A. Porous grain of chalcopyrite, bornite, and chalcocite in claystone Sample 129-802A-56R-4, 27-31 cm. Grain is approximately $50 \mu \mathrm{m}$ across. B. Pyrite and marcasite in chert Sample 129-800A-10R-1, 8-10 cm. Aggregates are approximately $20 \mu \mathrm{m}$ across.

has $\delta^{34} \mathrm{~S}=-30.9 \%$. Sulfides occur as 5 - to $20-\mu \mathrm{m}$ round grains of chalcopyrite, partly replaced by bornite. Larger porous grains, up to $50 \mu \mathrm{m}$ in size, of chalcopyrite + bornite + chalcocite are also present (Fig. 6), and Cu oxides and pyrite were identified by EDS. Although bulk metal contents were not measured, the abundance of $\mathrm{Cu}$ sulfides is unusual for sediments and, combined with their location close to basement, suggests that a component of metalliferous sediment from ridgecrest hydrothermal activity may be present in this unit.

\section{Radiolarite and Chert}

Sulfur was extracted from two radiolarite samples, from the bases of Holes $800 \mathrm{~A}$ and $801 \mathrm{~B}$. Sulfur is dominated by sulfate, with little or no pyrite-sulfur present (Table 2), consistent with the generally oxidized nature of the sediments and the low sedimentation rates. Red, semi-opaque aggregates (RSOs) are abundant in these samples, and only traces of fine (1-2 $\mu \mathrm{m})$ pyrite are present as inclusions in 


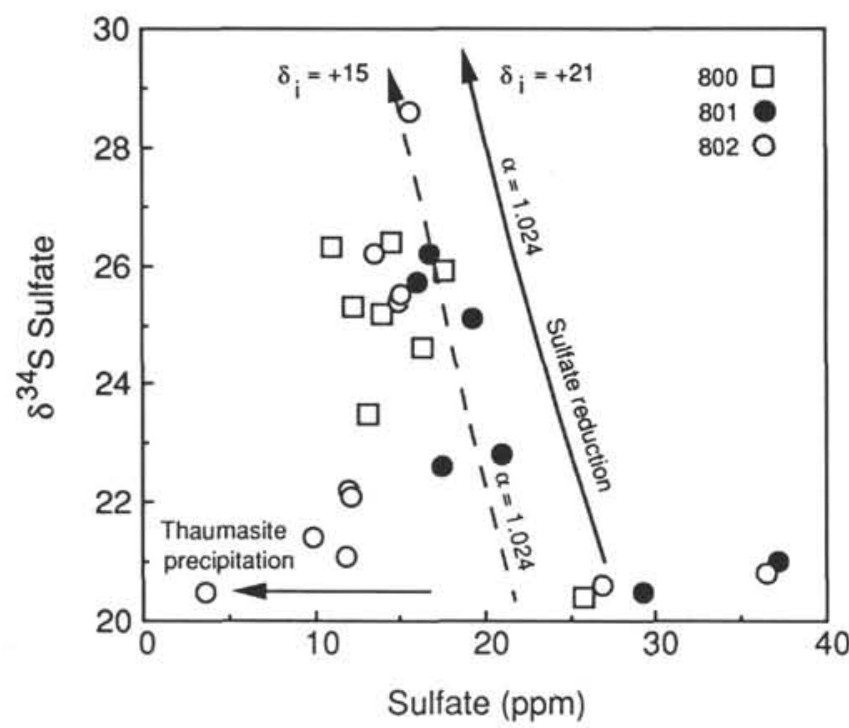

Figure 7. $\delta^{34} \mathrm{~S}$ vs. concentration for interstitial water sulfate. Lines indicate Rayleigh fractionation trends for closed-system reduction of seawater sulfate, starting with modern seawater (solid line $=\delta_{\mathrm{i}}=+21 \%$ ) and Cretaceous seawater (dashed line $=\delta_{\mathrm{i}}=+15 \%$ ). Horizontal arrow indicates the trend for interstitial waters affected by the extraction of sulfate by thaumasite precipitation. Data from Table 2 and Lancelot, Larson, et al. (1990).

chalcedony. Isotopic analysis yielded $\delta^{34} \mathrm{~S}$ values of $+21.0 \%$ to $-23.5 \%$ for water-soluble sulfate and $+16.8 \%$ or acid-soluble sulfate. These are consistent with a seawater source for the pore fluids, combined with some oxidized sulfide in the acid-soluble sulfate fraction. There was not enough pyrite sulfur present to analyze isotopically.

The single chert Sample 129-800A-10R-1, 8-10 cm (Table 2), has the highest total sulfur content analyzed ( $4420 \mathrm{ppm})$, and is dominated by pyrite-sulfur $(4020 \mathrm{ppm})$, with a few hundred parts per million of each water- and acid-soluble sulfate. Both water- and acid-soluble sulfate have low $\delta^{34} \mathrm{~S}$ values $(-15.9 \%$ and $-27.9 \%$, respectively) and appear to be affected by oxidized low- $\delta^{34} \mathrm{~S}$ sulfide. Pyrite-sulfur in this sample has $\delta^{34} \mathrm{~S}=-37.1 \%$. Both pyrite and marcasite are present as 1to $25-\mu \mathrm{m}$ spherules and aggregates throughout, with pyrite replacing and as overgrowths on marcasite (Fig. 6).

\section{Basement Rocks}

Secondary pyrite and marcasite occur in veins in the basalts with smectite and carbonate and disseminated in the rocks. Pyrite and marcasite separated from veins have $\delta^{34} \mathrm{~S}$ values of $-18.1 \%$ to $-41.7 \%$ (Table 2). These values are similar to pyrites in other seafloor basalts altered at low temperatures (about $0 \%$ to $-33 \%$, Krouse et al., 1977). Such negative values could be attributed to bacterial sulfate reduction, but the lack of an organic carbon source in the basalts suggests that an inorganic process is more likely. Andrews (1980) proposed that igneous sulfides $\left(\delta^{34} \mathrm{~S}=0 \%\right.$ a, Sakai et al., 1984) are partially oxidized to unstable intermediate oxidation sulfur species (sulfite and thiosulfate), which then disproportionate into sulfate and sulfide. Isotopic fractionation during disproportionation results in low- $\delta^{34} \mathrm{~S}$ sulfide, which is fixed as secondary pyrite, and higher $\delta^{34} \mathrm{~S}$ sulfate, which is lost from the rock.

\section{DISCUSSION}

The low $\delta^{34} \mathrm{~S}$ values for pyrite-sulfur in the sediments are consistent with formation of pyrite from sulfide derived from bacterial reduction of seawater sulfate. Isotopic fractionation during this process typically yields sulfide depleted in ${ }^{34} \mathrm{~S}$ by $25 \%$ to $60 \%$ relative to seawater sulfate (Goldhaber and Kaplan, 1974). The observed $\delta^{34} \mathrm{~S}$ values for pyrite from Leg $129(-4.8 \%$ oto $-37.1 \%)$ fall within this range relative to present-day seawater (+20.9\%c; Rees et al., 1978).

Bacterial reduction of sulfate in the upper few centimeters to tens of centimeters of reducing, fine-grained sediments generally occurs in an open system, with relatively constant pore-water sulfate concentrations maintained by the input of seawater sulfate by diffusion, advection, and bioturbation (Berner, 1964; Goldhaber and Kaplan, 1980; Chanton et al., 1987). The isotopic fractionation between sulfate and sulfide is about $-40 \%$ to $-60 \%$ in these settings, depending on such factors as the rate of sulfate reduction, organic carbon content, and sedimentation rate (Goldhaber and Kaplan, 1974). At greater depths in various organic-rich shelf and marginal basin sediments, the concentration of pore water sulfate decreases with depth, while the $\delta^{34} \mathrm{~S}$ of sulfate increases (Hartmann and Nielsen, 1969; Goldhaber and Kaplan, 1974, 1980; Sweeney and Kaplan, 1980). These trends have been modeled in two ways: (1) closed-system reduction of buried seawater sulfate (Sweeney and Kaplan, 1980) and (2) diffusive input of sulfate to the sediment, with enhanced downward diffusion of ${ }^{32} \mathrm{SO}_{4}$ due to the preferential reduction and loss of ${ }^{32} \mathrm{SO}_{4}$ as sulfide at depth (Goldhaber and Kaplan, 1980; Chanton et al., 1987). In either case, the pore-water sulfate data for various organic-rich shelf and marginal basin sediments fall along lines that are similar from site to site on plots of $\delta^{34} \mathrm{~S}$ vs. concentration. These lines can be approximated by a Rayleigh fractionation equation for closed-system sulfate reduction, with $\alpha=1.024$ (Goldhaber and Kaplan, 1974; Sweeney and Kaplan, 1980). In particular, data for interstitial waters at depths up to $250 \mathrm{mbsf}$ from DSDP Sites 26 and 27 in the North Atlantic fall along this Rayleigh fractionation line and are interpreted to reflect the closed-system reduction of buried seawater sulfate (Goldhaber and Kaplan, 1974; Sweeney and Kaplan, 1980).

A plot of $\delta^{34} S$ vs. concentration of IW sulfate for the Leg 129 samples is shown in Figure 7. Also plotted is the calculated Rayleigh fractionation trend for closed-system sulfate reduction, with $\alpha=$ 1.024 and starting from present-day seawater composition. All the Leg 129 data fall to the left and below this line. There are several factors that likely contribute to this discrepancy, including the variation in $\delta^{34} S$ of seawater sulfate in the past, precipitation of sulfatebearing phases with little or no sulfur isotopic fractionation, variation in isotopic fractionation during bacterial reduction, plus various sedimentological parameters (e.g., varying accumulation rates, presence of hiatuses, and differences in compositions and porosity of units).

The $\delta^{34} \mathrm{~S}$ of seawater sulfate has varied in the past, increasing from the present value of $+20.9 \%$ to about $+23 \%$ in the Miocene, then decreasing to about $+15 \%$ in the Lower Cretaceous (Claypool et al., 1980). Based on sediment age-depth curves (Lancelot, Larson, et al., 1990 ) and the $\delta^{34} \mathrm{~S}$-time curve for seawater (Claypool et al., 1980), the $\delta^{34} \mathrm{~S}$ of contemporaneous seawater sulfate has been plotted vs. depth in sediment for Leg 129 cores (Figs. 2-4). The profiles for Sites 800 and 801 are similar and indicate that the $\delta^{34}$ S of contemporaneous seawater sulfate throughout the sedimentation history of these sites was generally lower than that of present-day seawater, averaging about $+16 \%$ (Figs. 2 and 3 ). The $\delta^{34} \mathrm{~S}$ of seawater contemporaneous with Hole $802 \mathrm{~A}$ sediments is generally closer to modern seawater, although it decreases to about $+16 \%$ at the base of the sediments (Fig. 4). Using a starting $\delta^{34} \mathrm{~S}$ value of $+15 \%$ of Cretaceous seawater sulfate gives the curve shown by the dashed line in Figure 7 for IW sulfate evolution during closed-system sulfate reduction. Excluding the IW samples from the pelagic clay at the top of Hole 801A, which are essentially modern seawater, the data for Site 801 scatter about this line of evolution for closed-system reduction of sulfate with an initial $\delta^{34} \mathrm{~S}$ of $+15 \%$ (Fig. 7). This suggests that lower $\delta^{34} \mathrm{~S}$ values of seawater in the past might have contributed to the deviation of the Site 801 data from the reduction trend of modern seawater sulfate. The closed-system reduction trend for Cretaceous seawater passes through the righthand side of the field of IW data for Holes $800 \mathrm{~A}$ and $802 \mathrm{~A}$, but most of the points fall at even lower sulfate concentrations than the 
Cretaceous seawater trend indicating that other processes must also have occurred.

Several points from Hole $802 \mathrm{~A}$ fall at low sulfate concentrations, with little or no isotopic fractionation from modern seawater sulfate (Fig. 7). These low-sulfate points fall within the depth range 83-162 mbsf (Fig. 4), the same range in which the sulfate-bearing phase thaumasite occurs with zeolites in fractures and vugs. The $\delta^{34} \mathrm{~S}$ of sulfate in thaumasite is indistinguishable from the values for IW sulfate in this depth interval $(+19.5 \%$ to $+20.4 \%$, Table 2$)$, suggesting that little or no fractionation of sulfur isotopes occurs during the precipitation of thaumasite. Thus, sulfate uptake by thaumasite likely accounts for the low sulfate contents of pore fluids that have $\delta^{34} \mathrm{~S}$ values similar to present-day seawater in Hole 802A (Fig. 7). The sediments in this 83-162 mbsf interval have low water- and acid-soluble sulfate contents, leading to low total sulfur contents (Table 2). This implies that if the low sulfate contents of the sediments are caused by the uptake of sulfate by thaumasite, then thaumasite must reside mainly in veins. This implication is borne out by mineralogical studies of the sediments (Karpoff et al., this volume).

Thaumasite has been identified only in the Unit II tuff of Hole $802 \mathrm{~A}$. Interstitial waters from this unit are significantly changed from seawater composition, which is attributed to extensive interaction of seawater with the highly reactive volcanic glass of this unit (Lancelot, Larson, et al., 1990; France-Lanord et al., this volume). Ca contents reach their maximum and $\mathrm{Mg}$ contents their minimum in the 83-162 mbsf interval where thaumasite occurs $(130 \mathrm{mM}$ and $0.2 \mathrm{mM}$, respectively, Lancelot, Larson, et al., 1990; France-Lanord et al., this volume). This suggests that thaumasite forms only from the most highly altered IW fluids, and that thaumasite precipitation may be related to the very high $\mathrm{Ca}$ contents.

The concentration of sulfate in the IW sample from $44 \mathrm{mbsf}$ in Hole $802 \mathrm{~A}$, just above the thaumasite zone, is about $30 \%$ greater than seawater (36.5 mM vs. $27 \mathrm{mM}$, Fig. 4). The isotopic composition of this sulfate $\left(\delta^{34} \mathrm{~S}=+20.8 \%\right.$, Table 2$)$ is identical to overlying seawater, as is its chloride concentration (Lancelot, Larson, et al., 1990). It is possible that the increase in sulfate in this sample could be related to the dissolution of thaumasite at the top of the underlying "thaumasite zone," with the consequent release of sulfate to pore waters. At present there is no mineralogical support for this interpretation, however. A similar elevated sulfate concentration occurs in IW from the pelagic clay near the top of Hole 801A (Fig. 3). The $\delta^{34} \mathrm{~S}$ of sulfate and concentration of chloride in this sample are both identical to seawater (Table 2; Lancelot, Larson, et al., 1990). Thaumasite has not been identified in this core and is unlikely to occur in pelagic clay or the underlying chert and porcellanite. The increased sulfate concentration could be due to the release of sulfate through dissolution of carbonate or to release of sulfate from the clay component (e.g., aluminosulfate decomposition, Volkov and Rozanov, 1983).

Another factor that may have affected the isotopic composition of IW sulfate is variation in the magnitude of isotopic fractionation during bacterial sulfate reduction. In laboratory studies of bacterial sulfate reduction, the magnitude of the instantaneous fractionation between sulfate and sulfide is inversely proportional to the rate of sulfate reduction (Goldhaber and Kaplan, 1974). The rate of sulfate reduction is positively correlated with the sedimentation rate and with the organic carbon accumulation rate (Toth and Lerman, 1977; Berner, 1978; Canfield, 1991), suggesting that variations in the latter could result in deviation of the Leg 129 IW data from that of organic-rich sediments. For example, movement of a site from a low-productivity zone into a higher productivity area (e.g., equatorial zone) would result in an increased rate of deposition of organic carbon, greater sulfate reduction rates, and consequently lower isotopic fractionation. Closed-system reduction with lower fractionation would shift the lines in Figure 7 to the left, toward the field of the Leg 129 IW data.

Profiles for Site 801 illustrate the effects of various sedimentary parameters on the geochemistry of sulfur in sediments and IW (Fig. 3 ). The low accumulation rates and high porosity of the pelagic clays in Unit I allow exchange with seawater and domination of sulfur in these sediments by seawater sulfate. The underlying low-porosity cherts and porcellanites of Unit II are interpreted to form a barrier to diffusion between the volcanogenic turbidites beneath and overlying seawater (Lancelot, Larson, et al., 1990; France-Lanord et al., this volume). This can be seen in the elevated $\mathrm{Ca}$ and decreased $\mathrm{Mg}$ and sulfate contents of IW in the volcanogenic turbidites (Lancelot, Larson, et al., 1990; France-Lanord et al., this volume). This effect is also observed in profiles of the isotopic composition of IW sulfate at Site 801 , where sulfate has seawater $\delta^{34} S$ values in the uppermost sediments, but elevated values of $+25.1 \%$ to $+26.4 \%$ in the lower volcanogenic units due to sulfate reduction. Beneath the volcanogenic Unit III in Hole 801B, the $\delta^{34} \mathrm{~S}$ of IW sulfate decreases to values of $22.6 \%$ to $22.8 \%$ (Fig. 3) and IW concentrations of $\mathrm{Ca}$ are lower and $\mathrm{Mg}$ higher in the radiolarite and claystone at about $450 \mathrm{mbsf}$ at the base of the sediment section than in the overlying volcanogenic turbidites (Lancelot, Larson, et al., 1990). The chemistry of IW at the bottom of the sediment section is thus less reacted and closer to seawater in composition than in the overlying volcanogenic unit. A very low-porosity $(<10 \%)$ interval occurs from 350 to $400 \mathrm{mbsf}$ in Unit IV (Lancelot, Larson, et al., 1990), and provides a barrier to diffusion beneath Unit III. Similar diffusional barriers occur in other DSDP holes (Gieskes and Lawrence, 1981) and can also be seen in Hole $800 \mathrm{~A}$, where the cherts, porcellanites, and limestones of Units II and III separate overlying seawater from more reacted fluids in the volcanogenic turbidites of Unit IV (low $\mathrm{SO}_{4}$ and $\mathrm{Mg}$ concentrations and increased sulfate $\delta^{34} \mathrm{~S}$ and Ca concentrations, Fig. 2; Lancelot, Larson, et al. 1990; France-Lanord et al., this volume).

The less reacted composition of IW fluids in Unit V at the base of Hole $801 \mathrm{~B}$ can be attributed to variations in sedimentation history and compositions. Sediments in Unit V accumulated at a much slower rate than the volcaniclastic turbidites of Unit III (1.3 compared to 5-12 $\mathrm{m} / \mathrm{m}$.y., respectively, Lancelot, Larson, et al., 1990), and hiatuses occur within Unit $\mathrm{V}$ and at the base of Unit III. The low sedimentation rate and exposure to seawater during nondeposition would allow exchange of pore fluids in Unit V with seawater and oxidation of the sediment. Unit $\mathrm{V}$ also lacks the highly reactive volcanic components that cause the commonly observed $\mathrm{Mg}$ depletions and $\mathrm{Ca}$ enrichments of IW within the sediment column (Gieskes and Lawrence, 1981). Trapping of buried seawater in Unit V by overlying cherts in Unit IV isolated these fluids from the highly reactive volcaniclastics of Unit III and preserved their less evolved compositions. A similar process may have occurred at the base of Hole $800 \mathrm{~A}$, where sedimentation rates were very low ( $3 \mathrm{~m} / \mathrm{m}$.y.) in Unit $\mathrm{V}$ and a hiatus occurred prior to the deposition of Unit IV volcaniclastics, resulting in the presence of less reacted sulfate in Unit V (i.e., lower $\delta^{34} \mathrm{~S}$, Fig. 2 and Table 2).

\section{SUMMARY AND POSSIBLE IMPLICATIONS FOR CYCLING OF SULFUR IN SUBDUCTION ZONES}

Sulfur contents and isotopic compositions for sediments recovered on Leg 129 have been determined. Pelagic clays contain about $1200 \mathrm{ppm} \mathrm{S}$, essentially all as sulfate, with about $65 \%$ of the total present as water-soluble sulfate and $35 \%$ as acid-soluble sulfate. Volcanogenic turbidites contain about $400 \mathrm{ppm} \mathrm{S}$, with subequal amounts of water- and acid-soluble sulfate and 10\%-20\% of total S as pyrite-S. Chalk averages about $400 \mathrm{ppm}$ total S, with all sulfur present as sulfate, approximately $60 \%$ as water soluble and $40 \%$ as acid soluble. A single claystone sample from the base of Hole 802A has high total sulfur $(1500 \mathrm{ppm})$, with $84 \%$ of the sulfur present as pyrite-S. The abundance of $\mathrm{Cu}$ sulfides and oxides suggests the presence of a metalliferous sediment component. Radiolarites contain about $350 \mathrm{ppm} \mathrm{S}$, subequally distributed between water- and acid-soluble sulfates. A single sample of lithified chert has high total sulfur $(4020 \mathrm{ppm})$, essentially all as pyrite-S $(91 \%)$. Isotopic data suggest that most of the small amount of sulfate present is derived from oxidation of sulfide. Pyrite and marcasite from veins in basalts 
underlying the sediments have $\delta^{34} \mathrm{~S}$ values of $-18.1 \%$ to $-41.7 \%$, interpreted to be due to isotopic fractionation during partial oxidation of igneous sulfides.

Sulfate in pore waters ranges from seawater concentrations to nearly zero, and has $\delta^{34} \mathrm{~S}$ values ranging from seawater values $(+20 \%)$ to slightly enriched in ${ }^{34} \mathrm{~S}\left(+28 \%\right.$ ). Pyrite sulfur has $\delta^{34} \mathrm{~S}$ values of $-4.8 \%$ to $-37.1 \%$. These general trends are attributed to bacterial reduction of seawater sulfate, but the data do not fit simple models for downward diffusion of sulfate or closed-system reduction of buried sulfate. These complications are due to variations in the $\delta^{34} \mathrm{~S}$ of seawater sulfate in the past, uptake of sulfate by thaumasite without isotopic fractionation in the tuff Unit II in Hole 802A, the presence of cherts that act as barriers to diffusion, and possible variations in isotopic fractionation during bacterial sulfate reduction caused by differences in sedimentation rates of organic carbon.

One of the goals of this work is to provide some constraints on the mass and isotopic composition of sulfur in deep-sea sediments that could contribute to the recycling of sulfur in subduction zones. The Leg 129 samples are somewhat biased in their large proportion of volcaniclastic sediments, which are apparently characteristic of the Cretaceous in the western Pacific, plus the poor recovery of cherts, which may be underrepresented in the present study. Overall, sulfur in the Leg 129 sediments is dominated by sulfate, with about $50 \%$ of the total sulfur present as water-soluble sulfate with $\delta^{34} \mathrm{~S}$ of $+20 \%$, approximately $35 \%$ of total sulfur as acid-soluble sulfate with $\delta^{34} \mathrm{~S}$ of $+15 \%$, and only about $15 \%$ as pyrite sulfur with $\delta^{34} \mathrm{~S}$ about $-20 \%$. Mass balance using these values and a total sulfur content of $850 \mathrm{ppm}$ gives a bulk $\delta^{34} \mathrm{~S}$ for sedimentary sulfur of about $+12 \%$ a

These results are significantly influenced by two samples with high pyrite-sulfur contents $(>1000 \mathrm{ppm}$, whereas most other samples contain $<100$ ppm pyrite-S, Table 2). Omitting these two samples from the calculations results in pyrite-S comprising only about $5 \%$ of the total sulfur, which then has $\delta^{34} \mathrm{~S}$ about $+16 \%$. Similarly, if such high pyrite-S sediments were more abundant, then the bulk $\delta^{34} S$ of the sediment would be lower. Thus, as might be expected, the isotopic composition of sulfur in deep-sea sediments is highly dependent on the amount of reduced sulfur fixed in the sediments, which in turn is a function of the depositional environment and the history of the sediment. Because bacterial sulfate reduction in marine sediments requires organic carbon, sedimentary pyrite contents are positively correlated with organic carbon contents for marine sediments (Goldhaber and Kaplan, 1974). The spatial distribution of sulfate reduction rates in pelagic sediments corresponds closely with primary organic carbon production (Canfield, 1991). Areas of high productivity (e.g., equatorial zones and western margins of continents) produce sediments rich in organic carbon and sedimentary pyrite, whereas pelagic clays and carbonates have high sulfate contents and low organic carbon and sedimentary pyrite contents (Cann, Langseth, Honnorez, Von Herzen, White, et al., 1983; Lancelot, Larson, et al., 1990; Table 2 ). Depending on the proportions of sediment types, a wide range of bulk sediment $\delta^{34} \mathrm{~S}$ values can occur, from seawater values down to strongly negative values (e.g., $-22 \%$ for the Morocco Basin in the Atlantic; Lew, 1981). Such variations in the isotopic composition of the subducted sediment component could contribute to some of the wide range in $\delta^{34} \mathrm{~S}$ values of sulfides in mantle xenoliths (-5\% to +9\%; Chaussidon et al., 1987; Chaussidon and Lorand, 1990). More data for sediments from different deep-sea sites with different sedimentary histories are required to further constrain the sedimentary sulfur component during subduction.

The behavior of sedimentary sulfate during subduction may differ significantly from that of sedimentary sulfide. Because sulfate occurs dominantly in the pore fluids, it is much more mobile than sulfide and subject to loss from the sediments during subduction-related compaction. Inorganic sulfate reduction may become important as the sediment pile is heated and, depending on fluid migration processes, could result in further mass and isotopic fractionation of sulfur within the sedimentary pile. It would be of interest to study sulfur in fluids and sediments in both modern and ancient accretionary prisms in order to provide constraints on isotopic fractionation and migration of sulfur during subduction, and to ultimately constrain the amount and isotopic composition of sulfur recycled into the mantle.

\section{ACKNOWLEDGMENTS}

This work was supported by NSF OCE-9018136. The authors thank the Leg 129 shipboard scientific party and ODP staff for carrying out the specialized sampling of cores and pore waters. Discussions with C. France-Lanord, J. Gieskes, A. Karpoff, A. Magenheim, and L. Walter are appreciated. Reviews by Martin Goldhaber and Laurel Woodruff helped to improve the manuscript.

\section{REFERENCES}

Alt, J. C., and Anderson, T. F., 1991. The mineralogy and isotopic composition of sulfur in Layer 3 gabbros from the Indian Ocean, ODP Hole 735B. In Von Herzen, R. P., Robinson, P. T., et al., Proc. ODP, Sci. Results, 118: College Station, TX (Ocean Drilling Program), 113-125.

Alt, J. C., Anderson, T. F., and Bonnell, L., 1989. The geochemistry of sulfur in a $1.3 \mathrm{~km}$ section through the upper oceanic crust, DSDP Hole 504B. Geochim. Cosmochim. Acta, 53:1011-1023.

Andrews, A. J., 1980. On the effect of low-temperature seawater-basalt interaction on the distribution of sulfur in oceanic crust, Layer 2. Earth Planet. Sci. Lett., 46:68-80.

Berner, R. A., 1964. An idealized model of dissolved sulfate distribution in recent sediments. Geochim. Cosmochim. Acta, 28:1497-1503.

, 1978. Sulfate reduction and the rate of deposition of marine sediments. Earth Planet. Sci. Lett., 37:492-498.

, 1982 . Burial of organic carbon and pyrite sulfur in the modern ocean: its geochemical and environmental significance. Am. J. Sci., 282:451-473.

Bonnell, L., and Anderson, T. F., 1987. Sulfur isotopic variations in nodular and disseminated pyrite: Hole 603B. In van Hinte, J. E., Wise, S. W., Jr., et al., Init. Repts. DSDP, 93: Washington (U.S. Govt. Printing Office), 1257-1262.

Burdett, J. W., Arthur, M. A., and Richardson, M., 1989. A Neogene seawater sulfur isotope age curve from calcareous pelagic microfossils. Earth Planet. Sci. Lett., 94:189-198.

Canfield, D. R., 1991. Sulfate reduction in deep-sea sediments. Am. J. Sci., 291:177-188.

Canfield, D. R., Raiswell, R., Westrich, J. T., Reaves, C. M., and Berner, R. A., 1986. The use of chromium reduction in the analysis of reduced inorganic sulfur in sediments and shales. Chem. Geol., 54:149-155.

Cann, J. R., Langseth, M. G., Honnorez, J., Von Herzen, R. P., White, S. M., et al., 1983. Init. Repts. DSDP, 69: Washington (U.S. Govt. Printing Office).

Chanton, J. P., Martens, C. S., and Golhaber, M. B., 1987. Biogeochemical cycling in an organic-rich coastal marine basin. 8. A sulfur isotopic budget balanced by differential diffusion across the sediment-water interface. Geochim. Cosmochim. Acta, 51:1201-1208.

Chaussidon, M., Albarede, F., and Sheppard, S.M.F., 1987. Sulphur isotope heterogeneity in the mantle from ion microprobe measurements of sulphide inclusions in diamonds. Nature, 330:242-244.

Chaussidon, M., and Lorand, J. P., 1990. Sulphur isotope composition of orogenic spinel lherzoite massifs from Ariege (Northeastern Pyrenees, France): an ion microprobe study. Geochim. Cosmochim. Acta, 54:2835-2846.

Claypool, G. C., Holser, W. T., Kaplan, I. R., Sakai, H., and Zak, I., 1980. The age curves of sulfur and oxygen isotopes in marine sulfate and their mutual interpretation. Chem. Geol., 28:199-260.

Gieskes, J. M., and Lawrence, J. R., 1981. Alteration of volcanic material in deep sea sediments: evidence from the chemical composition of interstitial waters from deep sea drilling cores. Geochim. Cosmochim. Acta, 45:1687-1703.

Goldhaber, M. B., and Kaplan, I. R., 1974. The sulfur cycle. In Goldberg, E. D. (Ed.), The Sea (Vol. 5): New York (Wiley Interscience), 569-655.

1980. Mechanisms of sulfur incorporation and isotope fractionation during early diagenesis in sediments of the Gulf of California. Mar. Chem., 9:95-143.

Halas, S., Shakur, A., and Krouse, H. R., 1982. A modified method of $\mathrm{SO}_{2}$ extraction from sulphates for isotopic analyusis using $\mathrm{NaPO}_{3}$. Isotopenpraxis, $18: 433-435$

Hartmann, U. M., and Nielsen, H., 1969. $\delta^{34} \mathrm{~S}$ werte in rezenten meeres-sedimenten und ihre deutung am beispiel einiger sedimentprofile aus der westlichen ostsee. Geol. Rundsch., 58:621-655. 
Hut, G., 1987. Consultants' Group Meeting on Stable Isotope Reference Samples for Geochemical and Hydrological Investigations. Vienna (Int. Atomic Energy Agency).

Kaplan, I. R., Emery, K. O., and Rittenberg, S. C., 1963. The distribution and isotopic abundance of sulfur in recent marine sediments off southern California. Geochim. Cosmochim. Acta, 27:297-331.

Krouse, H. R., Brown, H. M., and Farquaharson, R. B., 1977. Sulfur isotope composition of sulfides and sulfates, DSDP Leg 37. Can. J. Earth Sci., 14:787-793.

Lancelot, Y., Larson, R. L., et al., 1990. Proc. ODP, Init. Repts., 129: College Station, TX (Ocean Drilling Program).

Lew, M., 1981. The distribution of some major and trace elements in sediments of the Atlantic Ocean (DSDP samples). 1. The distribution of sulphur, sulphur isotopes, and $\mathrm{Mn}, \mathrm{Fe}, \mathrm{Zn}$, and Cu. Chem. Geol., 33:205-224.

Rees, C. E., Jenkins, W. J., and Monster, J., 1978. The sulphur isotopic composition of ocean water sulphate. Geochim. Cosmochim. Acta, 42:377-381.

Rye, R. O., Luhr, J. F., and Wasserman, M. D., 1984. Sulfur and oxygen isotopic systematics of the 1982 eruptions of El Chichon volcano, Chiapas, Mexico. J. Volcanol. Geotherm. Res., 23:109-123.
Sakai, H., DesMarais, D. J., Ueda, A., and Moore, J. G., 1984. Concentrations and isotope ratios of carbon, nitrogen, and sulfur in ocean-floor basalts. Geochim. Cosmochim. Acta, 48:2430-2441.

Sweeney, R. E., and Kaplan, I. R., 1980. Diagenetic sulfate reduction in marine sediments. Mar. Chem., 9:165-174.

Toth, D. J., and Lerman, A., 1977. Organic matter reactivity and sedimentation rates in the oceans. Am. J. Sci., 277:465-485.

Ueda, A., and Sakai, H., 1984. Sulfur isotope study of quaternary volcanic rocks from the Japanese Islands Arc. Geochim. Cosmochim. Acta, 48:1837-1848.

Volkov, I. L., and Rozanov, A. G., 1983. The sulphur cycle in the oceans. In Ivanov, M. V., and Freney, J. R. (Eds.), The Global Biogeochemical Sulphur Cycle: Chichester (Wiley), 357-448.

Date of initial receipt: 4 June 1991

Date of acceptance: 8 October 1991

Ms 129B-125 